\title{
Fertility age couples motivation on cervical cancer early detection
}

\author{
Siti Nurul Khotimah" ${ }^{1 *}$, Dwi Ernawati ${ }^{2}$ \\ 1,2Universitas ‘Aisyiyah Yogyakarta, jl. Siliwangi No.63 Mlangi Nogotirto Sleman, Yogyakarta (55292), Indonesia \\ ${ }^{1}$ sitinurulkhotimah1988@gmail.com*; ${ }^{2}$ dwiernawati09@unisayogya.ac.id \\ *corresponding author
}

Submission date: 24 Maret 2021, Receipt date: 7 April 2021, Publication date: 1 November 2021

\begin{abstract}
This research aims to get the results from the fertility age couples' motivation on cervical cancer early detection. The preparation of a scoping review adapted the Arksey \& O'Malley framework consisted of 5 stages: research questions with the PEOs framework (Population, Exposure, and Outcomes), searching literature using relevant databases. From the 12 articles used to consist of 3 themes, namely sexual and reproductive health problems, sexual health problems, and sexual and reproductive health. The conclusion of the research are motivation and early detection of cervical cancer is a public health problem that has serious implications for adolescents. There is a need to provide women or youth with appropriate information and education about sexual and reproductive health.
\end{abstract}

Keywords: motivation; cervical cancer; fertility age couples; early detection

\section{INTRODUCTION}

Motivation is the impulse that drives people to do something. It can determine the ability to fulfill the individual needs (Arkiang, 2016). Motivation in the health sector has a significant role. Motivation is used to prevent disease. It will encourage someone to learn about the disease, such as the cause, prevention, effect, and treatment method. Motivation is influenced by physical and mental factors, heredity factors, environment, age maturity, intrinsic factors (knowledge, education, and job), facilities and infrastructure, socio-culture, and the media used (Arkiang, 2016).

The education can be obtained through formal and informal channels (Gustiana, Dewi, \& Nurchayati, 2014). Government agencies, non-governmental organizations, and cancer care groups often carry out cervical cancer promotion or counseling. That activity is an effort to create a community with conducive health behavior through health education to increase the community's knowledge, attitudes, and behavior. The Health Office already has a health promotion program through the citizen health center, including reproductive health material. However, the health education that is being carried out is not specific. It has not been followed up with concrete actions such as early detection.

Most women in the world mostly faced cervical cancer. After breast cancer, cervical cancer becomes second cancer infecting women. Cervical cancer disease is forecasted to increase by nearly $25 \%$ over the next ten years. Compared with modern countries, the annual number of female deaths due to cervical cancer in developed 
countries exceeds 270,000 (Nicolas Gaudin, 2013). According to the 2013 Basic Health Research (Riskesdas) data, Indonesia's cancer prevalence rate is 4.1 cases per 1,000 people or 330,000. The highest cancer in Indononesia for women is breast and cervical cancer. In view of assessments by Globocan, the International Agency for Research and Cancer (IARC) in 2012, the rate of breast cancer was 40 each 100,000 women, and cervical cancer growth was 17 each 100,000 women. (Dewi, 2014).

According to the 2013 Data and Information Center of the Ministry of Health of the Republic of Indonesia, the highest prevalence rate of cervical cancer in Indonesia is 4.1 cases per 1,000 population (15\%) in Yogyakarta Special Region(Kesehatan \& Indonesia, 2011). Kulonprogo and Gunung Kidul districts are the areas with the most cervical cancer sufferers. In these two districts, cervical cancer patients reached $4.1 \%$ per 1,000 people. The two districts were used as a demonstrative program to vaccinate the Human Papilloma Virus (HPV) at the national level.

The midwives role for overcoming cervical cancer is the most effective way by conducting cervical tests and screening to determine the condition of the HPV virus. The HPV virus that causes cervical cancer is spread due to infections of the genitals transmitted by sexual contact. Currently, cervical cancer is first cancer that is dangerous and afflicts many women in the world. Because cervical cancer is challenging to detect from the start, most cervical cancer is discovered after the tumor grows in an advanced stage. Pap smears, HPV vaccine injections, and stop smoking can prevent cervical cancer. Besides, the way to prevent cervical cancer by applied a healthy life and making a religious approach.

The incidence of cervical cancer can actually be suppressed by carrying out primary prevention efforts such as increasing or intensifying outreach activities to the community to carry out a healthy lifestyle, avoiding risk factors for cancer, immunizing with the HPV vaccine and followed by early detection of cervical cancer through Pap smear or IVA examination. (visual inspection using acetic acid). Prevention efforts against cervical cancer will be influenced by the motivation of each individual. There is no effort to prevent the incidence of cervical cancer, it shows the low motivation in preventing cervical cancer itself. Based on this background, the researcher wants to conduct a literature study on the role of family and husband in early detection of cervical cancer.

\section{RESEARCH METHODS}

The preparation of the scoping review adapted the Arksey \& O'Malley framework, which consisted of 5 stages. Those determine research questions with the PEOs framework (Population, Exposure, and Outcomes), conducting literature searching using relevant databases. The selection of relevant studies using inclusion and exclusion criteria. Those are conducting a critical appraisal to assess the quality of literature, perform data extraction, analyze data, map themes, and report results. Assing the article quality using Joana Brigs. A prism flowchart is used to describe the flow of literature search. 


\section{Stage 1: Identification of Research Questions}

In this scoping review, the researchers focused on the motivation of fertility-aged couples to detect cervical cancer?

\section{Stage 2: Identification of relevant studies}

a. Inclusion and Exclusion Criteria

After identifying the scoping review questions, the next step is to identify the relevant articles. This step is done by specifying key parameters, such as:

Table 1. Inclusion and Exclusion Criteria Framework

\begin{tabular}{|ll|}
\hline \multicolumn{1}{|c|}{$\bullet$ Included Criteria } & $\bullet$ Excluded Criteria \\
\hline Original article & Opinion article \\
English language article & Review book \\
Articles from 2009-2019 & Health workers opinion \\
Primary/secondary research & Review article \\
$\begin{array}{l}\text { Discussing the experience in early cervical cancer } \\
\text { detection }\end{array}$ & \\
Relate with the impact of lack of motivation to detect & \\
early cervical cancer & \\
\hline
\end{tabular}

\section{Stage 3: Articles Selection}

In search of 3 databases and a reference list, the number of articles was 275 . The 275 articles were screened based on titles/abstracts related to fertility-age couples' motivation to detect cervical cancer early. It obtained 275 articles. Re-screen these articles to obtain articles that match the effect of menarche on sexual and reproductive health. A full-text search of 88 identified articles was carried out to filter the content of the articles. The results of filtering the articles' content, the population is suitable, and the critical appraisal results. Twelve articles will be used for the Scoping Review. 


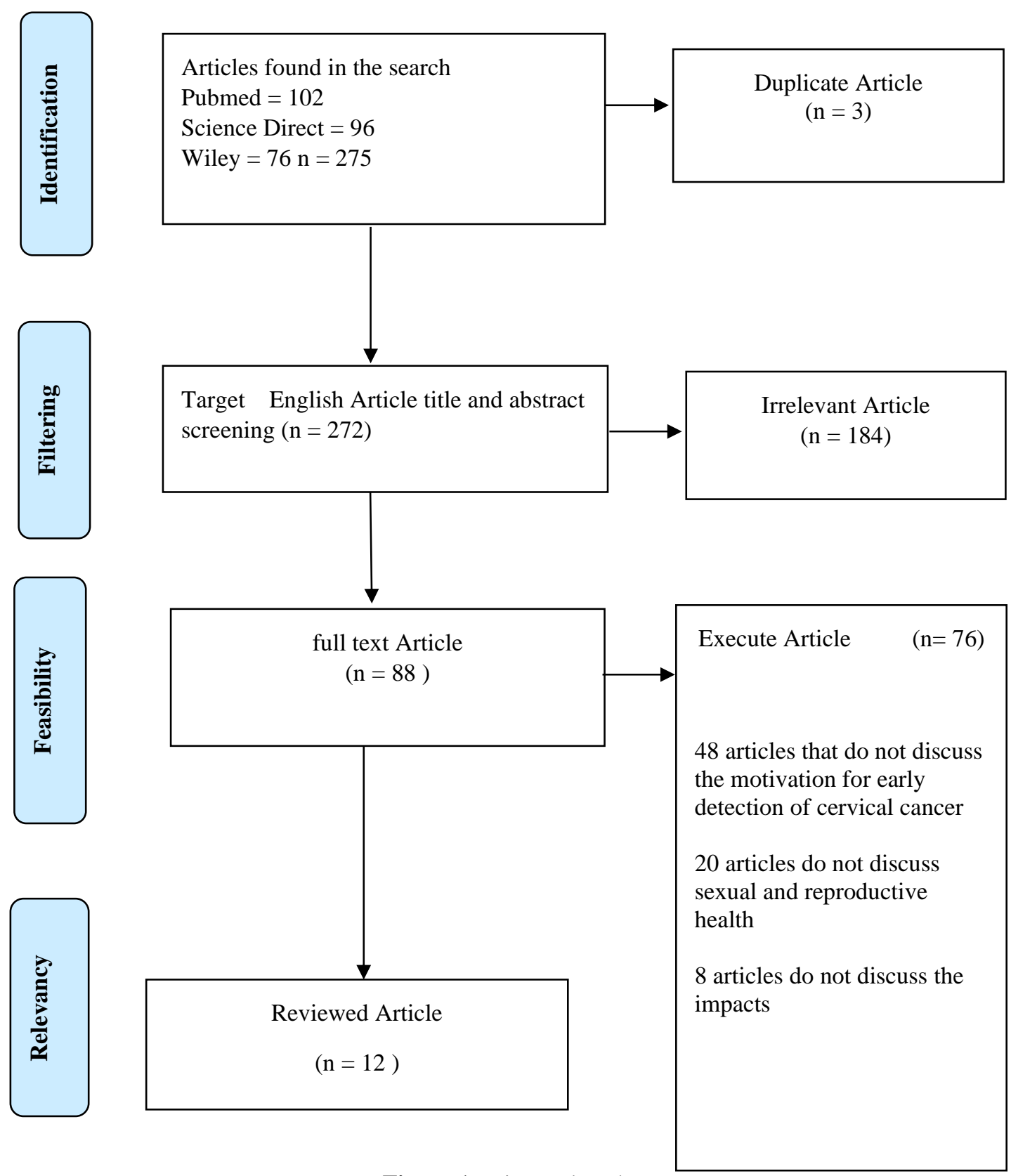

Figure 1. Prisma Flowchart

\section{Stage 4: Compile, summarize and report the results}

The data from 12 articles includes key criteria such as the location of study, the population of study, the objective of study, the methodology, and the findings or the recommendations. The author records the information independently and then compares the chart data. 
Table 2. Data Charting

\begin{tabular}{|c|c|c|}
\hline Author/year/ country/grade & $\begin{array}{l}\text { Study Design / } \\
\text { methods/sample }\end{array}$ & Results \\
\hline Bukirwa et, al (2015)/ Uganda & $\begin{array}{ll}\text { qualitative } & \text { by } \\
\text { interview, } & 24 \\
\text { respondents } & \\
\end{array}$ & $\begin{array}{l}\text { Inspirations for cervical cancer screening } \\
\text { typify the need for a far reaching evaluation, } \\
\text { finding, and the board, all things considered. } \\
\text { It is wont to ensure the physiological } \\
\text { condition, the concern of cervical cancer } \\
\text { growth results, doubt of danger, and a need } \\
\text { to keep up a fair relationship with medical } \\
\text { services staff. The resulting factors hurt } \\
\text { cervical screening business: Myths and } \\
\text { misguided judgments like the possibility that } \\
\text { women's ovaries and female inside } \\
\text { conceptive organ might be eliminated all } \\
\text { through the screening. The agony identified } \\
\text { with cervical screening, the concern of } \\
\text { disrobing, and women must keep up their } \\
\text { protection, danger of cancer growth saw low } \\
\text { cervix. A deficiency of clinical analysts } \\
\text { routinely gives cervical cancer schooling and } \\
\text { screening, and needs for providers and } \\
\text { patient transient request. The most } \\
\text { boundaries to continue screening typify } \\
\text { confined data and enthusiasm for the need } \\
\text { for re-screening and a nonattendance of } \\
\text { updates. }\end{array}$ \\
\hline Chigbu et al (2013)/ Nigeria & $\begin{array}{l}\text { Cross-sectional } \\
\text { with survey data, } \\
2,312 \text { female } \\
\text { participants. }\end{array}$ & $\begin{array}{l}\text { A sum of } 2,312 \text { women was interviewed. The } \\
\text { help from spouses and local area pioneers was } \\
\text { regularly reportable, propelling ladies to } \\
\text { partake in screenings. The majority of the } \\
\text { members expected prompt outcomes for } \\
\text { screening tests and quick treatment for any } \\
\text { variations from the norm distinguished. End } \\
\text { Community-based help for cervical cancer } \\
\text { screening is a proficient method for making } \\
\text { mindfulness in cervical disease screening. } \\
\text { Backing from life partners and local area } \\
\text { pioneers is important to consider a woman's } \\
\text { call to require the upside of cervical cancer } \\
\text { screening administrations in southeast African } \\
\text { nations. Quick outcomes and prompt medicines } \\
\text { can have the principal sway. Family and local } \\
\text { area investment ought to be coordinated into } \\
\text { cervical disease bar programs. This program } \\
\text { should accumulate with a "see and care" } \\
\text { approach. It ought to be important to deal with } \\
\text { the low use of cervical cancer screening } \\
\text { administrations in an African country and } \\
\text { comparative rustic settings. } \text { C } 2012 \\
\text { International Federation of Gynecology and } \\
\text { medication. A ton of this stockpile text is } \\
\text { expected to ask additional interpretation } \\
\text { information Send viewpoint Panel input. }\end{array}$ \\
\hline
\end{tabular}




\begin{tabular}{|c|c|c|}
\hline Compaore et, al (2016)/Afrika & $\begin{array}{l}\text { Qualitative by } \\
\text { interview, } 351 \\
\text { participants from } 3 \\
\text { groups }\end{array}$ & $\begin{array}{l}\text { Multivariate inventory relapse was } \\
\text { performed to anticipate cervical screening. } \\
\text { The investigation members were similarly } \\
\text { youthful (37.5 } \pm 10.7 \text { years) and } \\
\text { overwhelmed by metropolitan occupants } \\
(83.8 \%) \text {. There are the greater part of them } \\
\text { had a secondary school training. Over } 90 \% \\
\text { of members had known about cervical } \\
\text { disease. About } 55 \% \text { of them had middle level } \\
\text { information on the infection, screening, and } \\
\text { additionally hazard factors. The degree of } \\
\text { information on the country populace is lower } \\
\text { than that of the metropolitan populace. } \\
\text { Screening indicators included more } \\
\text { significant level of instruction. Low } \\
\text { mindfulness and financial obstructions bring } \\
\text { about the underutilization of screening } \\
\text { administrations for women. Inspiration and } \\
\text { schooling by medical services workers } \\
\text { square measure essential components for } \\
\text { expanding screening rates. Coordinated } \\
\text { patient and talented training programs in } \\
\text { gynecological administrations square } \\
\text { measure supreme to improve screening in } \\
\text { Burkina Faso and elective low-asset nations } \\
\text { in Africa a }\end{array}$ \\
\hline Interis et, al (2015)/Jamaika & $\begin{array}{l}\text { Cross-sectional, } \\
\text { with survey data, } \\
225 \text { women }\end{array}$ & $\begin{array}{l}\text { The structure was acquainted with survey } \\
\text { women's perspectives, information, hazard } \\
\text { factors, and cervical disease indications. The } \\
\text { move-in data and goal to the screen were } \\
\text { surveyed misuse matched t-tests and tests for } \\
\text { connecting extents. Members were followed } \\
\text { roughly a half year present mediation on } \\
\text { decide cervical malignant growth screening } \\
\text { rates. We discovered genuinely critical } \\
\text { increments from pre-test to post-test in the } \\
\text { level of inquiries addressed accurately and } \\
\text { the members' expectation to screen for } \\
\text { cervical malignant growth. The main } \\
\text { improvement was seen in reactions to } \\
\text { inquiries regarding information, } \\
\text { manifestations, and counteraction. A few } \\
\text { things expanded by } 62 \% \text { from pre-test to } \\
\text { post-test. Absolute } 123 \text { women reached for } \\
\text { follow-up, 50 (40.7\%) were screened for } \\
\text { cervical malignant growth. This hypothesis } \\
\text { based instructive mediation essentially } \\
\text { builds information and expectations for } \\
\text { cervical cancer growth screening. It very } \\
\text { well may be reproduced in comparable } \\
\text { settings to bring issues to light and expand } \\
\text { screening rates. }\end{array}$ \\
\hline Darj, Chalise, dan Shakya (2019 & $\begin{array}{l}\text { Qualitative with } \\
\text { Focus Group } \\
\text { Discussion (FGD), } \\
72 \text { men aged } 18-54\end{array}$ & $\begin{array}{l}\text { Findings: Women have misinterpretations } \\
\text { about screening and low degrees of } \\
\text { information. Socio-social hindrances, } \\
\text { specialist co-op conduct, geographic } \\
\text { difficulties, and restricted money were }\end{array}$ \\
\hline
\end{tabular}




\begin{tabular}{|c|c|c|}
\hline & $\begin{array}{l}\text { through } 6 \text { focus } \\
\text { groups. }\end{array}$ & $\begin{array}{l}\text { totally viewed as boundaries to going to the } \\
\text { screening place. Encouraging components, } \\
\text { for example, investment in mindfulness } \\
\text { projects and backing from families and } \\
\text { ladies' gatherings. Those can persuade } \\
\text { women to go to screening centers. End: } \\
\text { These discoveries add to the data on the } \\
\text { impression of Nepalese ladies with respect to } \\
\text { cervical disease screening. They may serve } \\
\text { to help the advancement of the Government } \\
\text { of Nepal's cervical disease screening and } \\
\text { treatment as an appropriate for every single } \\
\text { Nepalese women, at whatever point } \\
\text { required. }\end{array}$ \\
\hline Darlin et al. (2013)/ Swedia & $\begin{array}{l}\text { Qualitative by In- } \\
\text { Depth Interviews, } \\
242,678 \text { women, } \\
32-65 \text { years }\end{array}$ & $\begin{array}{l}\text { Reaction rates to HPV self-testing were } \\
\text { multiple times higher than those of adaptable } \\
\text { outpatient center solicitations ( } 147 / 1000 \\
\text { ladies }(14.7 \%) \text { contrasted with } 21 / 500 \\
(4.2 \%) \mathrm{p}<.0001) \text {. High danger (hours) - } \\
\text { HPV was found in } 10 / 147 \text { women who } \\
\text { examined themselves }(6.9 \%) \text {. } 7 / 10 \text { hours of } \\
\text { HPV positive women went to colposcopy, } \\
\text { however no HSIL was found. Among the } \\
\text { facility test ladies, } 2 / 21 \text { had jam-HPV, and } \\
1 / 21 \text { had HSIL. Explanations behind not } \\
\text { going to were "awkward with the vaginal } \\
\text { assessment," "feeling great," "absence of } \\
\text { time," and "the experience meet s hostile of } \\
\text { wellbeing laborers." }\end{array}$ \\
\hline Egawa-Takata et, al (2016)/Japar & $\begin{array}{l}\text { Cross-sectional, } \\
\text { with survey data, } \\
997 \text { mothers, ages } \\
40-60 \text { years. }\end{array}$ & $\begin{array}{l}\text { In the event that it is Compared with moms } \\
\text { who were not screened, women who went } \\
\text { through cervical disease screening had } \\
\text { altogether more information about cervical } \\
\text { cancer growth and screening ( } p<0.05 \text { ). } \\
\text { Moms' girl screened as of late got HPV } \\
\text { immunization more often than moms who } \\
\text { were not screened as of late ( } \mathrm{p}=0.018 \text { ). } \\
\text { Moms with a new screening history would in } \\
\text { general urge their little girls to go through } \\
\text { cervical cancer screening all the more } \\
\text { habitually ( } \mathrm{p}<0.05 \text { ). At the point when } \\
\text { moms were satisfactorily instructed about } \\
\text { cervical cancer and its screening, they were } \\
\text { essentially bound to suggest that their little } \\
\text { girl had it ( }<<0.0001) \text {. }\end{array}$ \\
\hline $\begin{array}{l}\text { Eze, Obiebi, and Umuago (2018) } \\
\text { Nigeria }\end{array}$ & $\begin{array}{l}\text { Cross-section, by } \\
\text { interview, } \\
\text { workers }\end{array}$ & $\begin{array}{l}\text { Most of respondents knew about cervical } \\
\text { cancer growth, however it was altogether } \\
\text { higher among women, } \mathrm{p}=0.001 \text {. The greater } \\
\text { part of the respondents, } 266(84.2 \%) \text {, were } \\
\text { under } 40 \text { years of age yet information about } \\
\text { cervical cancer growth screening diminished } \\
\text { by expanding age, } \mathrm{p}=0.039 \text {. Just } 92(29 \%) \\
\text { had great information on cervical screening. } \\
\text { Better information on cervical screening was } \\
\text { essentially connected with working in } \\
\text { clinical offices, working longer than two }\end{array}$ \\
\hline
\end{tabular}




\begin{tabular}{|c|c|c|}
\hline & & $\begin{array}{l}\text { years, and being female. At that point, all } \\
\text { ladies screened for cervical Ca, } 18(11 \%) \text { had } \\
\text { a Pap smear, and most of } 15(83 \%) \text { had } \\
\text { screened just a single time. Variables related } \\
\text { with screening are level of schooling, } \\
\text { working experience, and being in the clinical } \\
\text { office. Reasons given for not screening } \\
\text { incorporated the agony of the system, the } \\
\text { expense, and the postponement in getting } \\
\text { results. Ends: The information on cervical } \\
\text { screening isn't acceptable among DELSUTH } \\
\text { staff, and screening practice is likewise } \\
\text { wretched. They can get a profit by wellbeing } \\
\text { instruction and advancement programs } \\
\text { coordinated towards better screening } \\
\text { rehearses. The presentation of more } \\
\text { agreeable and more affordable screening } \\
\text { modalities, for example, VIA/VILI may } \\
\text { likewise build the ingestion. }\end{array}$ \\
\hline Hweissa, Lim, dan Su (2016)/ Li & $\begin{array}{l}\text { Qualitative with } \\
\text { In-depth } \\
\text { Interviews, } \\
\text { women }\end{array}$ & $\begin{array}{l}\text { The interviewed were recorded and } \\
\text { deciphered, at that point dissected utilizing } \\
\text { topical investigation. Our discoveries } \\
\text { propose that medical care suppliers don't } \\
\text { give sufficient data on cervical disease } \\
\text { screening for women going to medical } \\
\text { services offices. The outcomes feature the } \\
\text { pretended by medical care experts in } \\
\text { spurring women to go to cervical cancer } \\
\text { screening programs. At that point, the } \\
\text { requirement for wellbeing instruction from } \\
\text { medical care suppliers to offer important } \\
\text { guidance on screening. Then again, medical } \\
\text { services suppliers featured that executing a } \\
\text { cervical cancer growth screening update } \\
\text { framework would uphold them to build } \\
\text { screening participation. Likewise, medical } \\
\text { care specialist organizations underlined the } \\
\text { requirement for an instructive and } \\
\text { mindfulness crusade on cervical malignancy } \\
\text { screening among Libyan ladies. }\end{array}$ \\
\hline t & $\begin{array}{l}\text { Cross-sectional, } \\
\text { with survey data, } \\
25 \text { women, 25-65 } \\
\text { years }\end{array}$ & $\begin{array}{l}\text { The general overview reaction rate was } \\
63.8 \% \text { (981/1538), with } 447 \text { (45.6\%) } \\
\text { revealing they needed to gather themselves, } \\
\text { versus } 534(54.4 \%) \text { detailing that they didn't. } \\
\text { In the univariate investigation, women with } \\
\text { more than auxiliary schooling were bound to } \\
\text { gather autonomously. women who expected } \\
\text { to get a HPV versus Pap smear test were } 1.94 \\
\text { occasions bound to pick self-take. The } \\
\text { individuals who plan to self-gather had } \\
\text { altogether higher disposition scores toward } \\
\text { HPV self-assortment. Changed chances } \\
\text { proportions and 95\% certainty spans from } \\
\text { the multivariate examination indicated } \\
\text { mentalities toward self-assortment were the } \\
\text { lone critical factors anticipating ladies' aim }\end{array}$ \\
\hline
\end{tabular}




\begin{tabular}{|c|c|c|}
\hline & & $\begin{array}{l}\text { to submit without anyone else (OR 1.25; } \\
95 \% \text { CI: } 1.22,1.29 \text { ). }\end{array}$ \\
\hline Young et al. (2018)/ Inggris & $\begin{array}{l}\text { Qualitative } \\
\text { In-depth } \\
\begin{array}{l}\text { Interviews, } \\
\text { women }\end{array}\end{array}$ & $\begin{array}{l}\text { The outcomes } 34 \text { examinations met the } \\
\text { consideration rules. They are related with } \\
\text { eliminating the bosom, cervical, colorectal, } \\
\text { prostate, ovarium, and cellular breakdown in } \\
\text { the lungs. Three principle topics arose out of } \\
\text { the blend. These incorporate medical care } \\
\text { choices impacted by trust, adherence to } \\
\text { control, protection from control or } \\
\text { management, and saw inability to meet } \\
\text { social, strict, and phonetic necessities. The } \\
\text { 'dread of malignant growth screening' is a } \\
\text { helper and a hindrance from multiple points } \\
\text { of view and to various degrees. Procedures } \\
\text { for arranging moderate degrees of dread are } \\
\text { demonstrated. } \\
\text { incorporate making a talk on elective } \\
\text { individual dangers and the utilization of } \\
\text { screening as an adapting system, impacted } \\
\text { by convictions of disease and sound } \\
\text { inclination and success. }\end{array}$ \\
\hline Spencer et al. (2016) / Inggris & $\begin{array}{l}\text { Qualitative by In- } \\
\text { depth Interviews, } \\
43 \text { women of } \\
\text { children aged } 12- \\
13 \text { years }\end{array}$ & $\begin{array}{l}\text { Results } 97 / 606 \text { of the ones who reacted to the } \\
\text { survey altered their perspectives on cervical } \\
\text { screening. } 23 \text { women were talked with, } 10 \text { of } \\
\text { whom expressed positive changes, and } 13 \\
\text { didn't change. The greater part of them has } \\
\text { examined antibody data, including cervical } \\
\text { screening, with their little girls. Moms who } \\
\text { settled on sure change choices knew about } \\
\text { their girls' danger of creating cervical } \\
\text { disease, the requirement for future screening, } \\
\text { and the significance of their good example. } \\
\text { Thusly, the little girl turns into a 'critical } \\
\text { other' in fortifying their moms' cervical } \\
\text { assessments' inspiration. }\end{array}$ \\
\hline
\end{tabular}

\section{RESULTS AND DISCUSSION}

Based on data mapping, results were obtained are in the form of methods, countries, and themes of selected articles from 12 selected articles, 5 articles using crosssectional research methods, and 7 articles using qualitative methods. The motivation of early age couples towards early detection of cervical cancer, lack of knowledge, education and economics causes women to have a lack of motivation to ensure early detection of cervical cancer. Knowledge and information experienced by women, lack of pap smear and VIA examinations can cause cervical cancer. Early detection of cervical cancer that is too late will be fatal in women's reproductive health. Because the biggest cancer in Indonesia after breast cancer is cervical cancer. 


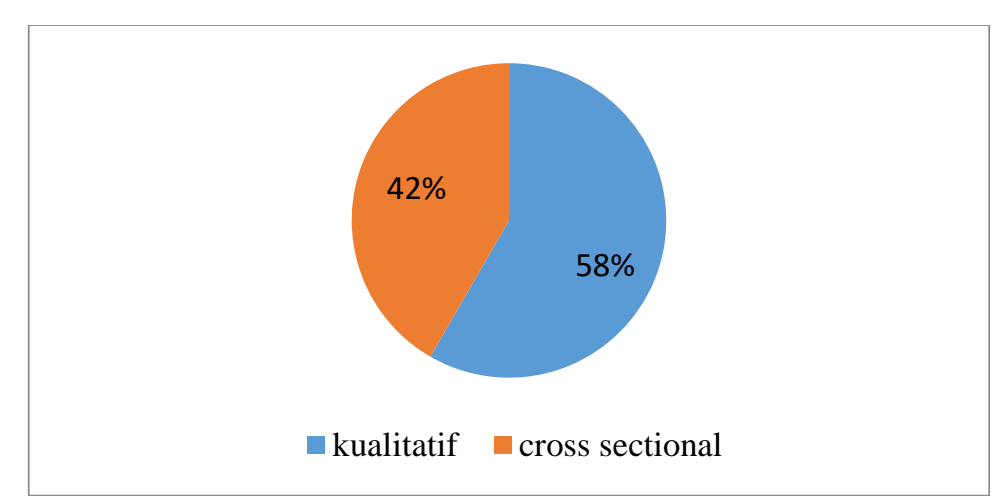

Figure 2. Characteristics of Research Methods



Figure 3. Characteristics of Developed and Modern Countries

Table 3. Mapping Data

\begin{tabular}{|c|c|c|c|}
\hline No & Theme & Sub-theme & Article \\
\hline \multirow[t]{3}{*}{1} & $\begin{array}{l}\text { Sexual and } \\
\text { reproductive } \\
\text { health problems }\end{array}$ & a. Early sexual & $4,5,6,7$ \\
\hline & & b. Medical workers & $2,3,5,7,9$ \\
\hline & & c. Less Motivated & $4,6,11$ \\
\hline \multirow[t]{2}{*}{2} & $\begin{array}{l}\text { Sexual and } \\
\text { reproductive } \\
\text { disease }\end{array}$ & a. STI (sexually transmitted infection) & 1,12 \\
\hline & & b. HIV & $1,2,7,9$ \\
\hline & $\begin{array}{l}\text { Affecting health } \\
\text { factors sexual }\end{array}$ & a. Education & $2,3,4,8,9$ \\
\hline & & b. Knowledge & 3,12 \\
\hline & & c. Economy & $2,3,4,7,9$ \\
\hline
\end{tabular}




\section{Characteristic}

\section{Sexual and Reproductive Health Problems}

a. Early Sexual

The research result was conducted by (Ajah et al., 2015). The mean age of the reproductive age partners is under 17 years - a total of 101 (21\%). Although $365(75.7 \%)$ women are aware of the importance of reproductive health, only $89(18.5 \%)$ of them are aware, and $88(8.9 \%)$ of them are less motivated towards reproductive health itself. Research shows that people who are under 17 years old have a higher risk of early sexual activity. The low age, partaking with men and society could assume a synergistic part with mindfulness, formal instruction, and free or supported administrations to expand the take-up of intentional cervical cancer growth screening (Young et al., 2017) (Abadeh, Ali, Bradley, \& Magalhaes, 2019).

\section{b. Medical Worker}

In this article (Eze et al., 2018). The cervical cancer views and screening practices in kids teaching hospitals in Southern African country. The hospital applied smart screening practices to be a decent health data supply and motivation to push the overall public's screening. The evaluation of their perceptions and practices of cervical screening might convey gaps. It might inspire efforts to boost leading indicators among them and also the broader population. Most respondents are attentive to cervical cancer; however, it is a better risk than women aged less than forty. However, the knowledge about cervical cancer screening decreases by increasing their age. They have good cervical filtering knowledge. A better knowledge of cervical screening was hugely related to clinically departmental work, work experience less than two years, and females. All women screened for cervical $\mathrm{Ca}$ had a Pap smear, and the majority experienced one screening. (Abamecha, Tena, \& Kiros, 2019), (Abounouh et al., 2019)

\section{c. Less Motivated}

In the article by ((Smith et al., 2014) (Ahmad et al., 2019). Women might not participate in cervical cancer screening (cultural, language, geographic, and access to sample barriers). Self-collection offers another to visiting a doctor for screening. The ladies embed an inspecting device into the cervical-vaginal waterway to assemble the example in a really non-public setting with self-assortment. The example is then conceived or sent for testing, wiping out the specialist's clinical forte assessment prerequisite. Studies assessing ladies' insights and retention of self-examining found that ladies ordinarily felt idealistic with respect to the methodology's exhibition. In British Columbia (B.C.), cervical disease screening is directed commonly through a populace based cervical malignant growth screening program. Exploration has indicated that inspecting can expand support rates in difficult to-reach and less-screened ladies in screening programs. It is critical to design a program to address cervical disease screening techniques. It will give a more coordinated advance through arranging the essential HPV test schedule for cervical malignant growth screening.(Aldohaian, Alshammari, \& Arafah, 2019).

\section{Sexual and reproductive diseases}

a. IMS (Sexually transmitted infections)

This review is found in an article that discusses sexually transmitted diseases or STDs in research (Compaore, Ouedraogo, \& Koanda, 2015). That article explained that 
the sexually transmitted diseases found among women who have never done early detection of cervical cancer. It is constrained by access to information; support from husbands is limited by the economy. Their daily expenses only rely on their husbands whose has uncertainty monthly. Our study also found that women's area is a significant factor in cervical malignancy screening. It either impacts screening or impacts different elements, including occupation and information or mindfulness. Women who live in metropolitan territories have a higher possibility of being screened than the individuals who go to semi-metropolitan regions. At that point, ladies in semi-metropolitan zones have a more prominent possibility of being screened than country ladies. Metropolitan women are bound to be utilized than their partners in semi-metropolitan and country territories. The degrees of information vary across the regions of home in our examination. Information on sickness, screening, and danger factors was higher in metropolitan zones than in semi-metropolitan and rustic territories. Studies directed in country Tanzania (Al-hasan et al., 2020) found a higher extent of ladies with low information levels. The place of residence and educational genes in Tanzania could be a cause of reference in the findings. Similar to a Bharat study, our findings passed in a very tertiary hospital, like this study. Visual review of the cervix is that the sole methodology out there for cervical screening in Upper Volta. The value is believed cheaper, as reported by most of the ladies during this study. Burkina Faso's government subsidizes visual review value to be cheaper for women in the Republic of Indonesia.(Darj et al., 2019a), (Oketch et al., 2019)

\section{b. HIV}

In the article by (Darlin et al., 2013b), totally, 25.5\% of those tested were HSV-2 positive, and 5.6\% were HIV positive. The efficiency of the cervical screening program depends primarily on the coverage of the program population. It depends on the acceptance of the invitation. Women who have not had a screening test for nine years or more appear very reluctant to reply to some invitation. They replied to the questions about why the test was performed not being present. The most common answers were "Not comfortable with vaginal examinations." The other common reasons were "lack of time," "feeling in good condition," or "unfriendly experiences of health workers." Self-sampling is a appropriate way of dealing with low competition. Then, satisfaction with screening efforts made to enhance adherence rates in organized community-based screening programs. (Darj, Chalise, \& Shakya, 2019b).

\section{Factors Affecting Sexual and Reproductive Health}

a. Education

Cervical cancer occurred in $87.9 \%$ of these study respondents, less than $72 \%$, and previously $74.4 \%$ in Nigeria and Uganda. However, this compares with the $65 \%$ reported in the U.K., which occurred in $75.1 \%$ of respondents. Then, less than $85.5 \%$ reported in Calabar, Nigeria. Cervical cancer and cervical cancer cases are severe. Lack of education and self-motivation (Chigbu et al., 2013).

b. Knowledge

The knowledge level is different between all women respondents. It consists of various education levels. There are has elementary student education levels to S1 education level. (Smith et al., 2014). 


\section{c. Economy}

The economy becomes one of the factors inhibiting access to women's reproductive health. The expensive costs conduct a test such as pap smears and IVA. The social gap causes the woman challenging to get motivation from their husband's roles. (Oketch et al., 2019). (Eze et al., 2018)

\section{CONCLUSION}

According to the results and discussion, the fertile age, couples' motivation to early detection of cervical cancer is a smaller amount. It is caused by an absence of information, education, and social science. The lack of knowledge and information about pap smears and IVA examinations trigger cervical cancer. Then, the late detection of cervical cancer will be fatal in women's reproductive health. The most significant cancer in Indonesia after breast cancer is cervical cancer.

\section{REFERENCES}

Abadeh, A., Ali, A. A., Bradley, G., \& Magalhaes, M. A. (2019). Increase in detection of oral cancer and precursor lesions by dentists: Evidence from an oral and maxillofacial pathology service. The Journal of the American Dental Association, 150(6), 531-539. https://doi.org/https://doi.org/10.1016/j.adaj.2019.01.026

Abamecha, F., Tena, A., \& Kiros, G. (2019). Psychographic predictors of intention to use cervical cancer screening services among women attending maternal and child health services in Southern Ethiopia: the theory of planned behavior (TPB) perspective. BMC Public Health, 19(1), 434. https://doi.org/10.1186/s12889-0196745-x

Abounouh, K., Aitraise, I., Benabou, A., Boussakri, I., Doumir, M. A., El Boussairi, C., ... Ezzikouri, S. (2019). Virus-associated human cancers in Moroccan population: From epidemiology to prospective research. Infection, Genetics and Evolution, 75, 103990. https://doi.org/https://doi.org/10.1016/j.meegid.2019.103990

Ahmad, F. A., Jeffe, D. B., Carpenter, C. R., Chernick, L. S., Stukus, K. S., Turco, M., ... Bailey, T. C. (2019). Emergency Department Directors Are Willing to Expand Reproductive Health Services for Adolescents. Journal of Pediatric and Adolescent Gynecology, $32(2)$, 170-174. https://doi.org/https://doi.org/10.1016/j.jpag.2018.09.011

Ajah, L. O., Onubogu, E. S., Anozie, O. B., Lawani, L. O., Iyoke, C. A., Onwe, E. O., \& Ajah, M. I. (2015). Adolescent reproductive health challenges among schoolgirls in southeast Nigeria: Role of knowledge of menstrual pattern and contraceptive adherence. Patient Preference and Adherence, 9, 1219-1224. https://doi.org/10.2147/PPA.S89258

Aldohaian, A. I., Alshammari, S. A., \& Arafah, D. M. (2019). Using the health belief model to assess beliefs and behaviors regarding cervical cancer screening among Saudi women: a cross-sectional observational study. BMC Women's Health, 19(1), 6. https://doi.org/10.1186/s12905-018-0701-2 
Arkiang, N. I. (2016). Hubungan dukungan suami dengan motivasi ibu dalam melakukan pencegahan kanker serviks di puskesmas kendal sari kota malang.

Bukirwa, A., Mutyoba, J. N., Mukasa, B. N., Karamagi, Y., Odiit, M., Kawuma, E., \& Wanyenze, R. K. (2015). Motivations and barriers to cervical cancer screening among HIV infected women in HIV care: a qualitative study. BMC Women's Health, 15, 82. https://doi.org/10.1186/s12905-015-0243-9

Chigbu, C. O., Onyebuchi, A. K., Ajah, L. O., \& Onwudiwe, E. N. (2013). International Journal of Gynecology and Obstetrics Motivations and preferences of rural Nigerian women undergoing cervical cancer screening via visual inspection with acetic acid. International Journal of Gynecology and Obstetrics, 120(3), 262-265. https://doi.org/10.1016/j.ijgo.2012.10.011

Compaore, S., Ouedraogo, C. M. R., \& Koanda, S. (2015). Barriers to Cervical Cancer Screening in Burkina Faso: Needs for Patient and Professional Education. https://doi.org/10.1007/s13187-015-0898-9

Compaore, S., Ouedraogo, C. M. R., Koanda, S., Haynatzki, G., Chamberlain, R. M., \& Soliman, A. S. (2016). Barriers to Cervical Cancer Screening in Burkina Faso: Needs for Patient and Professional Education. Journal of Cancer Education. https://doi.org/10.1007/s13187-015-0898-9

Darj, E., Chalise, P., \& Shakya, S. (2019a). Barriers and facilitators to cervical cancer screening in Nepal: A qualitative study. Sexual \& Reproductive Healthcare, 20, 2026. https://doi.org/https://doi.org/10.1016/j.srhc.2019.02.001

Darj, E., Chalise, P., \& Shakya, S. (2019b). Sexual \& Reproductive Healthcare Barriers and facilitators to cervical cancer screening in Nepal : A qualitative study. Sexual \& Reproductive Healthcare, 20(7491), 20-26. https://doi.org/10.1016/j.srhc.2019.02.001

Darlin, L., Borgfeldt, C., Forslund, O., Hénic, E., Hortlund, M., Dillner, J., \& Kannisto, P. (2013a). Comparison of use of vaginal HPV self-sampling and offering flexible appointments as strategies to reach long-term non-attending women in organized cervical screening. Journal of Clinical Virology. https://doi.org/10.1016/j.jcv.2013.06.029

Darlin, L., Borgfeldt, C., Forslund, O., Hénic, E., Hortlund, M., Dillner, J., \& Kannisto, P. (2013b). Comparison of use of vaginal HPV self-sampling and offering flexible appointments as strategies to reach long-term non-attending women in organized cervical screening. Journal of Clinical Virology, 58(1), 155-160. https://doi.org/https://doi.org/10.1016/j.jcv.2013.06.029

Dasar, R. K. (2013). Penyajian Pokok-Pokok Hasil Riset Kesehatan Dasar 2013.

Dewi, L. (2014). Faktor - Faktor Yang Berhubungan Dengan Perilaku Wanita Usia Subur Dalam Deteksi Dini Kanker Serviks Dengan Metode Pemeriksaan Inspeksi Visual Asam Asetat (Iva). ProNers. 
Egawa-Takata, T., Ueda, Y., Tanaka, Y., Morimoto, A., Kubota, S., Yagi, A., ... Shimura, K. (2016). Mothers' attitudes in Japan regarding cervical cancer screening correlates with intention to recommend cervical cancer screening for daughters. International Journal of Clinical Oncology, 21(5), 962-968. https://doi.org/10.1007/s10147-0160970-4

Eze, G. U., Obiebi, I. P., \& Umuago, I. J. (2018). Perspectives of cervical cancer and screening practices among staff of a teaching hospital in South-South Nigeria. Journal of Cancer Research and Practice, 5(2), 67-73. https://doi.org/https://doi.org/10.1016/j.jcrpr.2018.01.001

Gustiana, D., Dewi, Y. I., \& Nurchayati, S. (2014). Faktor-Faktor Yang Berhubungan Dengan Perilaku Pencegahan Kanker Serviks Pada Wanita Usia Subur. Jom Psik.

Hweissa, N. A., Lim, J. N. W., \& Su, T. T. (2016). Health-care providers' perceptions, attitudes towards and recommendation practice of cervical cancer screening. European Journal of Cancer Care, 25(5), 864-870. https://doi.org/10.1111/ecc.12537

Interis, E. C., Anakwenze, C. P., Aung, M., \& Jolly, P. E. (2015). Increasing Cervical Cancer Awareness and Screening in Jamaica: Effectiveness of a Theory-Based Educational Intervention, 1-11. https://doi.org/10.3390/ijerph13010053

Kesehatan, K., \& Indonesia, R. (2011). Kementerian Kesehatan Republik Indonesia Tahun 2011.

Nicolas Gaudin, V. T. (2013). International Agency for Research on Cancer (IARC), WHO. Latest world cancer statistics Global cancer burden rises to 14.1 million new cases in 2012: Marked increase in breast and cervix cancers must be addressed.

Oketch, S. Y., Kwena, Z., Choi, Y., Adewumi, K., Moghadassi, M., Bukusi, E. A., \& Huchko, M. J. (2019). Perspectives of women participating in a cervical cancer screening campaign with community-based HPV self-sampling in rural western Kenya: a qualitative study. BMC Women's Health, 19(1), 75. https://doi.org/10.1186/s12905-019-0778-2

Smith, L. W., Khurshed, F., van Niekerk, D. J., Krajden, M., Greene, S. B., Hobbs, S., ... Ogilvie, G. S. (2014). Women's intentions to self-collect samples for human papillomavirus testing in an organized cervical cancer screening program. $B M C$ Public Health, 14, 1060. https://doi.org/10.1186/1471-2458-14-1060

Spencer, A. M., Brabin, L., Roberts, S. A., Patnick, J., Elton, P., \& Verma, A. (2016). A qualitative study to assess the potential of the human papillomavirus vaccination programme to encourage under- screened mothers to attend for cervical screening, 119-126. https://doi.org/10.1136/jfprhc-2015-101283

Young, B., Bedford, L., Kendrick, D., Vedhara, K., Robertson, J. F. R., \& das Nair, R. (2018). Factors influencing the decision to attend screening for cancer in the UK: a meta-ethnography of qualitative research. Journal of Public Health (Oxford, England), 40(2), 315-339. https://doi.org/10.1093/pubmed/fdx026 
Young, B., Bedford, L., Kendrick, D., Vedhara, K., Robertson, J. F. R., \& Nair, R. (2017). Factors in $\mathrm{fl}$ uencing the decision to attend screening for cancer in the UK : a metaethnography of qualitative research, 1-25. https://doi.org/10.1093/pubmed/fdx026 